\title{
DYNAMICAL INDUSTRIAL SYSTEMS
}

\author{
K. Adendorff \\ Department of Industrial and Systems Engineering \\ University of Pretoria \\ annemarie@eng.up.ac.za
}

\begin{abstract}
There is widespread evidence that industrial systems do not consistently perform in a stable fashion regardless of how diligently they have been designed and operated. Operation of a system is often in a dynamic sense chaotic or verges on the chaotic. The essence of such performance deserves analysis using the tools of chaos theory.

\section{OPSOMMING}

Daar is voldoende getuienis dat industriële sisteme nie altyd stabiel funksioneer nie, ten spyte van die noulettendheid waarmee hulle ontwerp en bedryf word. Die gedrag van 'n sisteem is soms in 'n dinamiese sin chaoties of bykans chaoties. Sodanige sisteme verdien ontleding met behulp van die gereedskap van die warboelleer (chaosteorie).
\end{abstract}




\title{
1. INTRODUCTION
}

\author{
Ek slaap in die rus van die eeue gesus, \\ ongesien, ongehoord, \\ en dof en loom in my sonnedroom, \\ ongewek, ongestoord.
}

Jan F E Celliers [1]

The use of quantitative models of industrial processes is a widespread phenomenon. The models are either deterministic or probabilistic, often make use of iterative methods for purposes of optimisation, frequently only emphasize steady state conditions, are invariably non-linear, and are applied in widely divergent situations.

The advent of mathematical analysis of chaotic dynamical systems which describes the often unexpected behaviour of systems which to all intents and purposes should perform in the steady state, has furnished valuable tools to be used in analysing the vast array of manmachine systems which industrial engineers deal with, and which often display characteristics of instability.

Strange as it may seem, chaos has unexpectedly been found to exist in the simplest of deterministic dynamical systems.

"A decade later, chaos has become a shorthand name for a fast growing movement that is reshaping the fabric of the scientific establishment. Chaos conferences and chaos journals abound. ... At every major university and every major corporate research center some theorists ally themselves first with chaos and only second with their nominal specialities." (Gleick [2] )

A recent survey of industrial engineering journals and periodicals suggests that industrial engineers to a large degree are unaware of or ignore the existence of chaotic industrial systems.

Whether industrial quantitative models are for inventory systems, queueing systems, forecasting, quality control, replacement systems and many others, industrial engineers should emerge from their torpor and address this challenge with enthusiasm.

\section{AN INDUSTRIAL DYNAMICAL SYSTEM}

Soos 'n vlokkie skuim uit die sfere se ruim kom 'n wolkie aangesweef, maar hy groei in die blou tot 'n stapelbou van marmer wat krul en leef-

Jan F E Celliers [1]

The example that follows is of a rudimentary nature. It however serves to illustrate how dynamical analysis may be used to analyse a system which appears to have unstable features. 
Texts which deal with queueing models often contain statements such as "... computed under the assumption that the steady state has been reached", "... What to do if interarrival or service times are not exponential", or "We have demonstrated that closed-form solutions can be found, albeit with considerable computational burden, for transient behaviour of some queueing systems as long as the arrival and service rates remain constant. When the changes in rate occur with high frequency or with some continuous pattern, the system never reaches steady state in the usual sense of the word. Only transient solutions have meaning." (Giffin $\mathrm{WC}[3]$ ).

If the supposition is made that arrivals at a queue may be modelled by logistic mapping for purposes of iterative determination of transient operation, the essence of the iterative relationship may be given by (Stewart [4] )

$$
\mathrm{x}_{\mathrm{i}+1}=\mathrm{kx}_{\mathrm{i}}\left(1-\mathrm{x}_{\mathrm{i}}\right)
$$

where $\mathrm{k} \quad=\quad \mathrm{a}$ constant between 0 and 4 .

The value of arrival rate at iteration $i$ is then given by

$$
\lambda_{\mathrm{i}}=\mathrm{Nx}_{\mathrm{i}}
$$

where $\mathrm{N}=$ maximum arrival rate

If the further assumption is made that the queue is a single channel queue with statedependant service allowing service rate increases and decreases to match the queue length by using a pressure coefficient, then the service rate is given by (Giffin [3] )

$$
\mu_{\mathrm{n}}=\mathrm{n}^{\gamma} \mu \quad \mathrm{n}=1,2, \ldots
$$

where $\mu=$ expected service rate when there is only one customer in the system, and $\gamma=$ pressure coefficient which relates the service rate to the system state $(\gamma \geq 0)$.

The number of customers in the system is given iteratively by

$$
\mathrm{n}_{\mathrm{i}+1}=\mathrm{n}_{\mathrm{i}}+\lambda_{\mathrm{i}}-\mathrm{n}_{\mathrm{i}}^{\gamma} \mu
$$

The operation of the total system may be captured in the following feedback diagram which demonstrates how arrivals are generated by logistic mapping and how the service rate adapts to the number of customers in the system. 


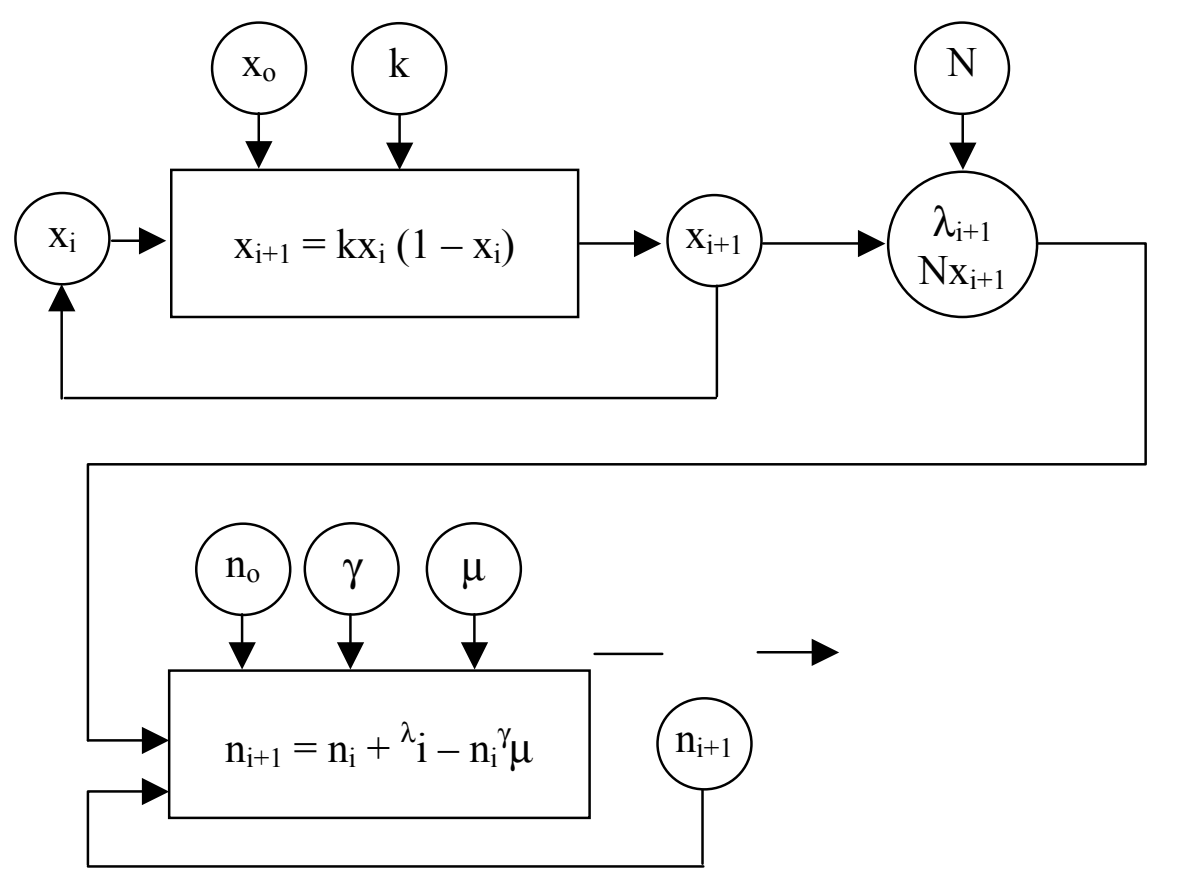

Figure 1: Feedback diagram of the queueing system

The following parameter values were chosen to illustrate the transient and eventual "orderly" behaviour of the system:

$$
\mathrm{N}=10 ; \quad \mathrm{n}_{\mathrm{o}}=0 ; \quad \gamma=0,3 \quad \text { and } \quad \mu=4
$$

Figures 2, 3 and 4 show the behaviour for logistic mapping parameters of $k=2,5 ; k=3,2$ and $\mathrm{k}=3,58$ respectively.

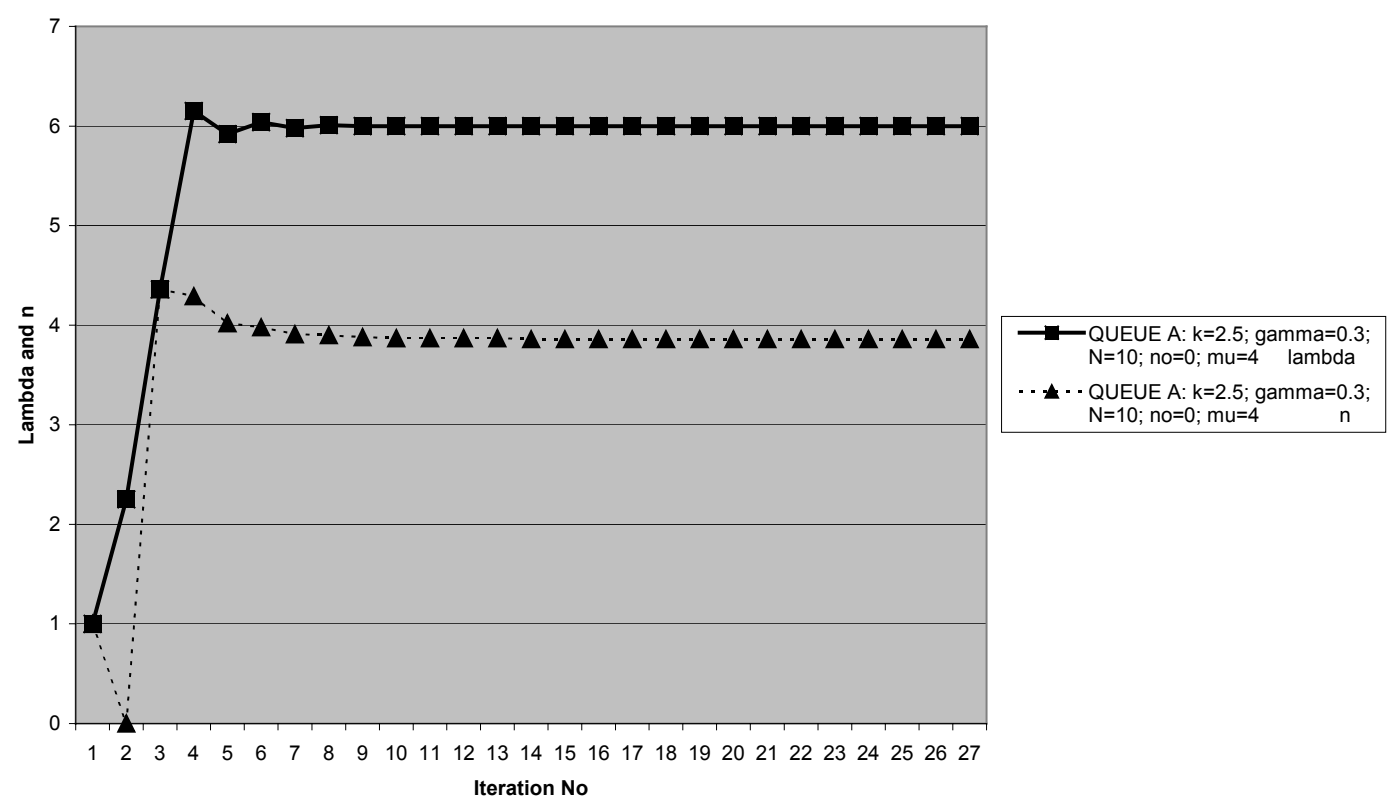

Figure 2: Queue A 


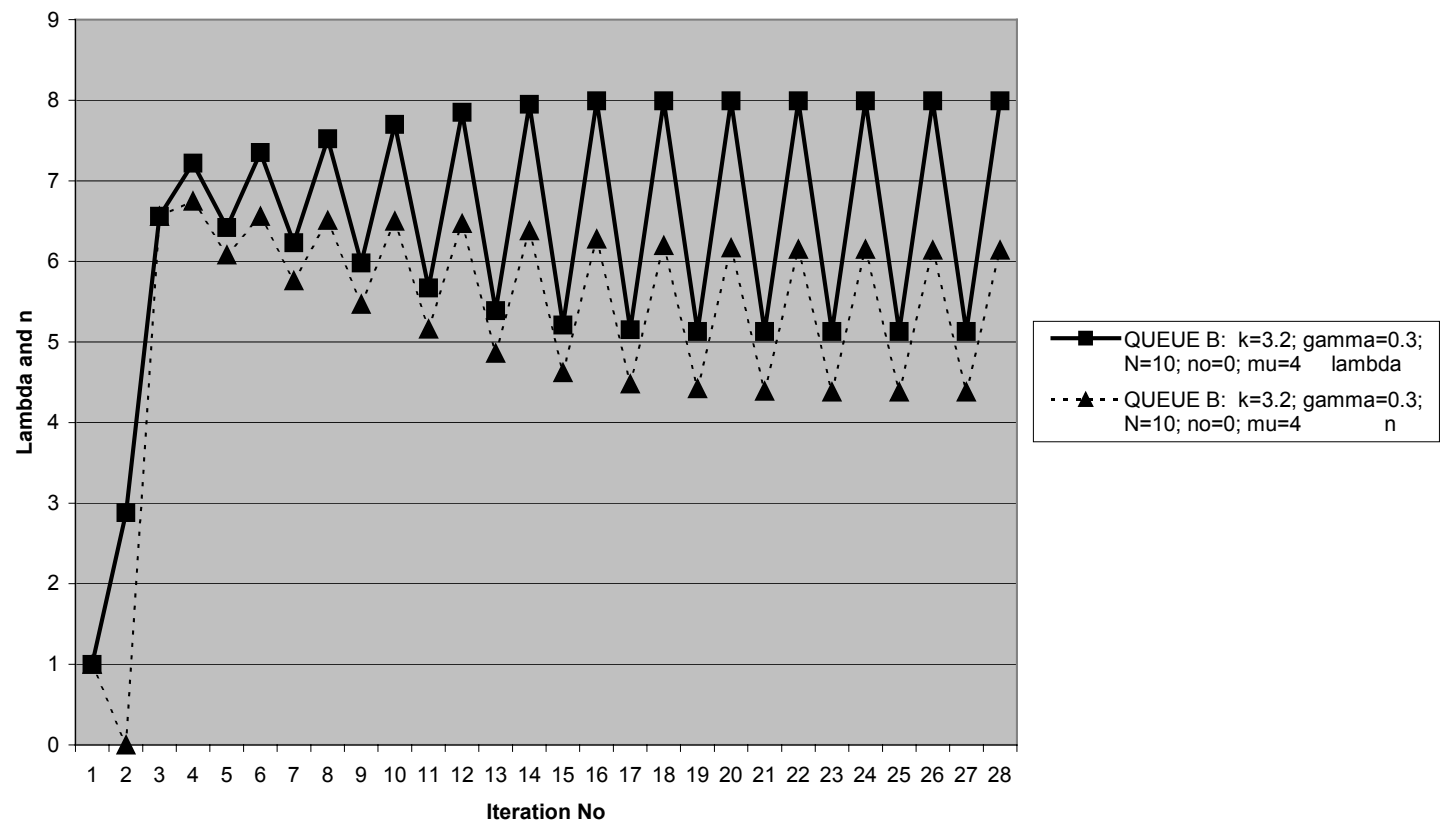

Figure 3: Queue B

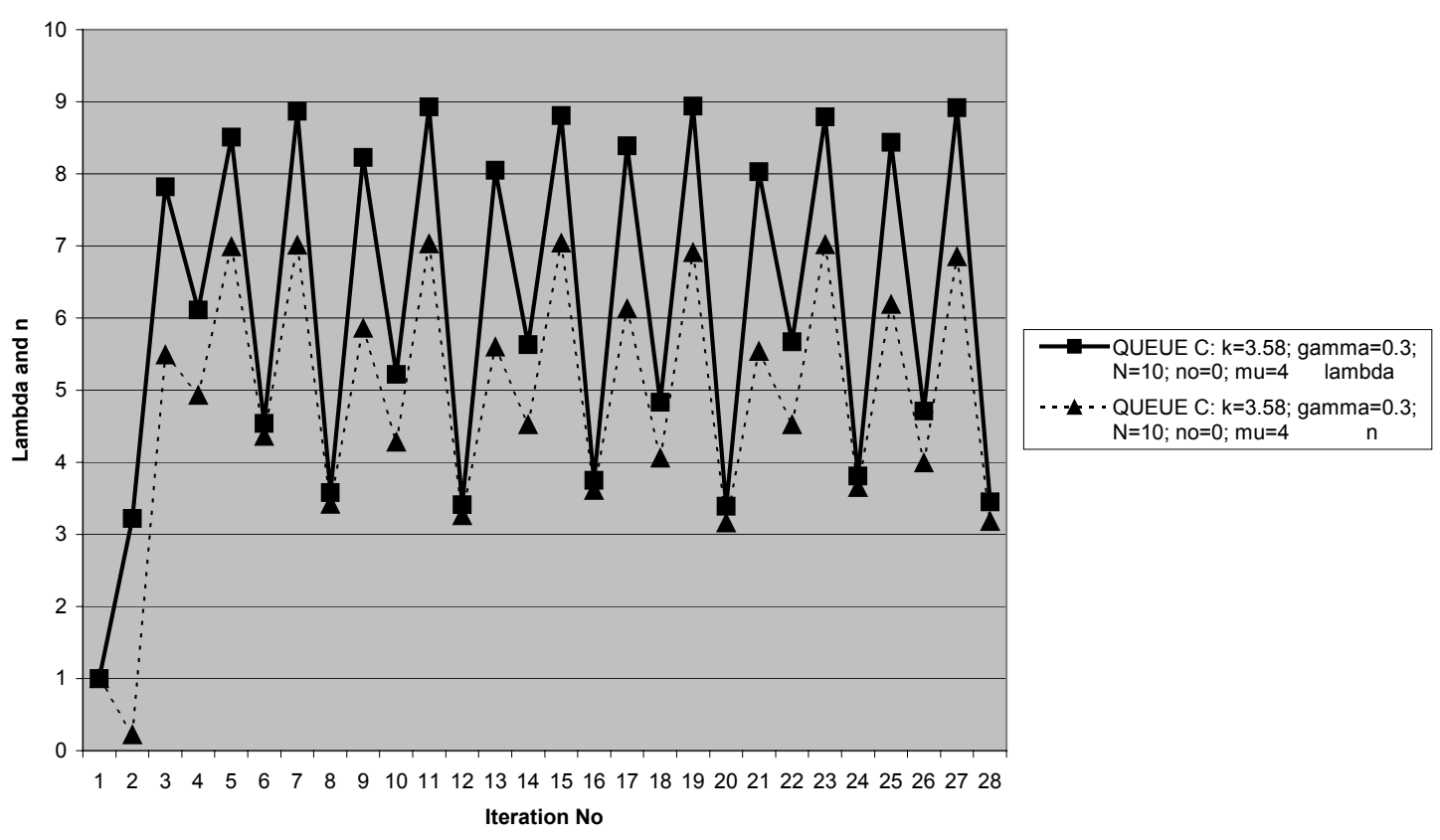

Figure 4: Queue C

The diagrams only give a limited view of the richness of performance that the system may exhibit for many other values of parameters, but do serve to emphasize that "order" does exist in the system.

Figure 5 on the other hand demonstrates system chaos when the logistic mapping input is based on a parameter value of $k=4$. 


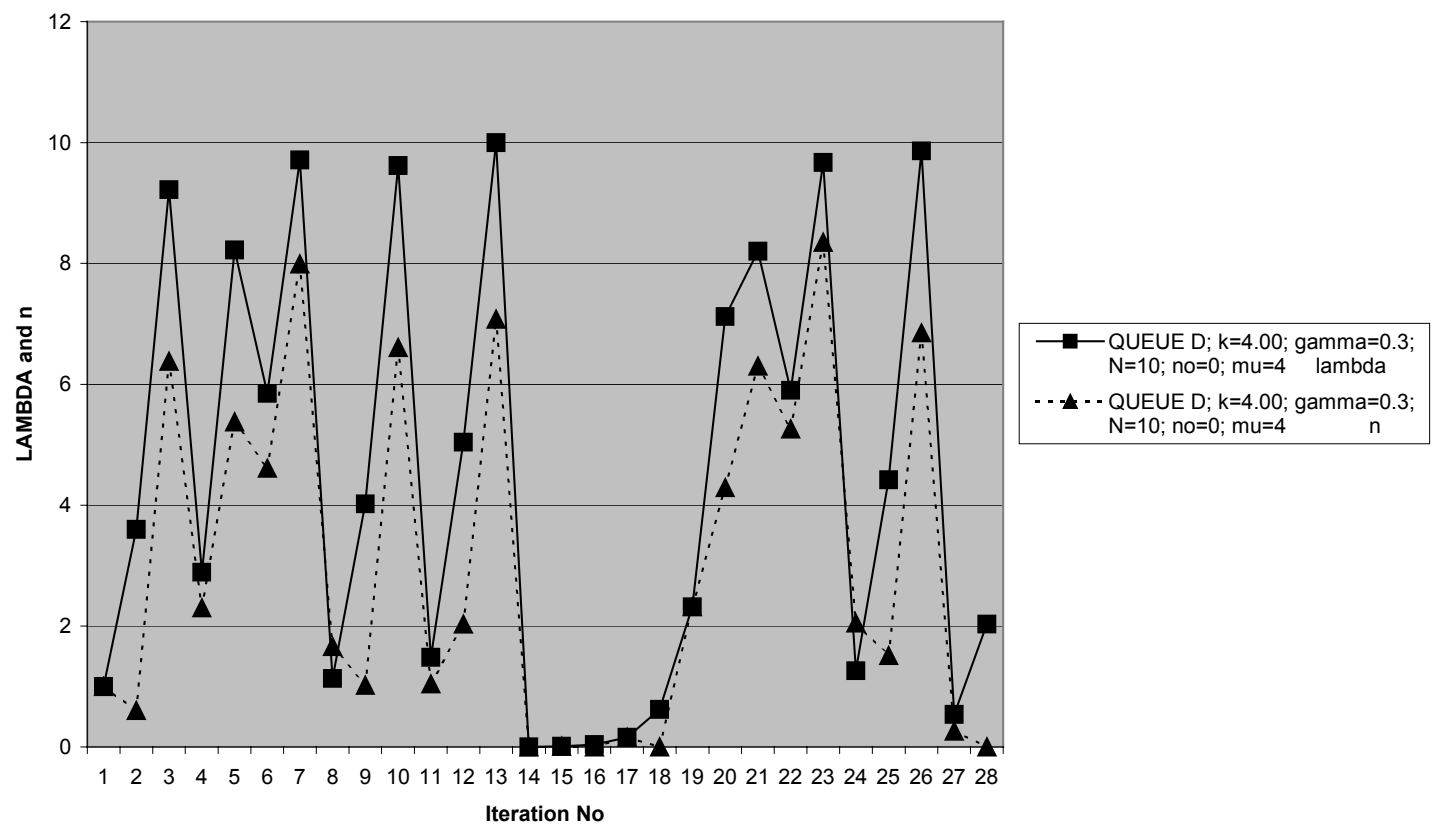

Figure 5: Queue D

\section{CONCLUSION}

The perfunctory tone of this essay emphasises its tutorial nature which should serve to rally enthusiasts in the field of quantitative modelling to seriously study dynamical systems (Devaney [5] ) and apply the available tools and excellent methods of analysis to practical industrial situations.

\section{REFERENCES}

[1] Cilliers, Jan F.E.: Die Vlakte en ander gedigte; Nasionale Pers, Bpk.; Kaapstad; 1934.

[2] Gleick, James: Chaos: Making a new science; Heinemann; London; 1988.

[3] Giffin, W.C.: Queueing: Basic theory and applications; Grid Publishing, Inc.

[4] Stewart, I.: Does God play dice?: The new mathematics of chaos; Penguin Books; London; 1997.

[5] Devaney, R.L.: Chaotic Dynamical Systems; Perseus Books Publishing; Cambridge, Massachusetts; 1992. 